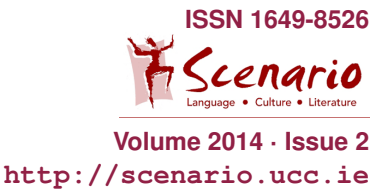

Short Film

\title{
Don't Play the Visual, Play the Emotion!
}

Fusing Drama and Film in the Teaching of Empathy

\section{Nataliia Dzhyma}

This contribution aims to introduce SCENARIO readers to my pedagogical practice at the Institute of International Relations, Taras Shevchenko National University of Kiev, which specializes in the training of future Ukrainian diplomats. In order to do so I have opted for the medium of film to give interested colleagues a vivid impression of how I propose to put empathy at the centre of diplomacy-related training programmes.

Since prehistoric times empathy has been understood to be a pillar of diplomacy. For Fliess (1942: 212), empathy is the ability "to step into another's shoes", for Etchefoyen (1996: 271) "to feel and understand what another feels", for Stover (2005: 209) "to take the role of the other and to view the world from different perspectives participating in the values, feelings and perceptions of another".

Drama Pedagogy, within the protective space of the imagination, offers many ways of "living through" the lives of others. It therefore seems ideally suited to play a key role in empathy-focused training programmes.

Sharing the well-known idea that being in public position is like being on stage but without a script, I developed a teaching concept which blends the diplomatic with the theatrical by using selected film clips in my classes, as a reference point for excercises that focus on feeling and on understanding what another feels. For guidance, I turned to those who are making cinema: script writers, directors, sound editors, camera-men, actors. These encounters gave me a deep insight into film as an art form and into how films are made. It became of special interest to me how actors work in the recording studio, how they empathize with a screen character and create this person's voice, facial expression, gestures etc. The major lesson learnt during my observations and research can perhaps be summed up in the words of the sound editor Al Nelson: "Don't play the visual, play the emotion!" (Isaza 2010)

The film shows my first steps into what could become a new, exciting area of research in the field of performative teaching and learning: the interrelationship between the medium of film and drama pedagogy.

Please note that the idea to forge closer links between drama pedagogy and film arose during a research visit to University College Cork. I wish to thank Dr. Manfred Schewe for his support and expert guidance and for encouraging me to use film as a medium through which to present my practice-based research. Please click here to download the film (large: $1.7 \mathrm{~Gb}$ ). 


\section{Bibliography}

Bordwell, David; Thompson, Kristin (2004): Film Art (7th ed). New York: McGraw-Hill

Brest, Martin (1992): Scent of Woman. Universal, DVD

Callas, Maria (1958): Casta Diva. https://www.youtube.com/watch?v=7rjGwS20V94 (Accessed 11 January 2015)

Carnicke, Sharon Marie (2000): Stanislavsky's System Pathways for the actor. In: Hodge, Alison (ed.): Twentieth Century Actor Training. London: Routledge, 11-36

Eisenstein, Sergey (1949): Film Form. New York: Harcourt Brace and Company

Eisenstein, Sergey (1986): The Film Sense. London: Faber \& Faber

Etchefoyen, Horacio (1996): The Fundamentals of Psychoanalytic Technique. London: Karnac Books

Fliess, Robert (1942): The Metapsychology of the Analyst. In: The Psychoanalytic Quaterly 11, 211-227

History Channel: Body Language Analysis of Barack Obama, John McCain and Hilary Clinton. https: / /www . youtube.com/watch?v=03VUuovloUM (Accessed 11 January 2015)

Isaza, Miguel (2010): How to Train your Dragon. Exclusive Interview with Randy Thom, Jonathan Null and Al Nelson. http://designingsound.org/2010/04/how-to-train-your-dragon-exclusiveinterview-with-randy-thom-jonathan-null-and-al-nelson/ (Accessed 11 January 2015)

Leanne, Shel (2009): Say it like Obama. New York: Professional Publishing

Obama, Barack (2004): Keynote address at the 2004 democratic national convention. http:// obamaspeeches.com/002-Keynote-Address-at-the2004-Democratic-National-Convention-Obama-Speech.htm (Accessed 11 January 2015)

Obama, Barack (2006): The Audacity of Hope. Thoughts on Reclaiming the American Dream. New York: Crown Publishing Group

Obama, Barack; Romney, Mitt (2012): The First Presidential Debate. http://www.nytimes.com/interactive/2012/10/04/us/politics/20120804denver-presidential-debate-obamaromney.html?_r=0\#/?annotation $=$ d91950519 (Accessed 8 January 2015)

President Barack Obama's Inaugural Address.

http://www.whitehouse.gov/blog/inaugural-address/ (Accessed 11 January 2015)

Pudovkin, Vsevolod (1974): Sobraniye sochinenii [Collected edition], vol. 1. Moscow: Iskusstvo 
Schewe, Manfred \& Beug, Joachim (1999): Learning and Teaching Culture from an Aesthetic Perspective. In: Intercultural Communication and Language Learning. Dublin: Royal Irish Academy - The Irish Association for Applied Linguistics, 119-134

Stover, William (2005): Teaching and Learning Empathy. An Interactive, online Diplomatic Simulation of Middle East Conflict. In: Journal of Political Science 2, 207-219.

http://www.scu.edu/crs/pdf/teaching-learning-empathy.pdf (Accessed 8 January 2015)

Wenner, Jann S. (2010): Obama in Command: The Rolling Stone Interview. In: Rolling Stone, http://www.rollingstone.com/politics/news/obamain-command-br-the-rolling-stone-interview-20100928 (Accessed 11 January 2015) 